\title{
INTRODUCING LOCAL WISDOM THROUGH NARRATIVE: TEACHING ENGLISH IN HIGHER EDUCATION
}

\author{
Titis Sulistyowati \\ Faculty of Teacher Training and Education, Muria Kudus University, Indonesia \\ Email: titis.sulistyowati@umk.ac.id \\ Sri Surachmi W \\ Faculty of Teacher Training and Education, Muria Kudus University, Indonesia \\ Email: sri.surachmi@umk.ac.id
}

\begin{abstract}
APA Citation: Sulistyowati, T., \& Surachmi, W. S. (2020). Introducing local wisdom through narrative: Teaching English in higher education. Indonesian EFL Journal, 6(1), 81-88. doi: 10.25134/ieflj.v6i1.2641.
\end{abstract}

\begin{abstract}
It is very important to introduce and continue the local narrative and their values to the next generation. This paper is part of a larger research on narrative writing for higher education level students organized in a genre writing class. In this paper, the writers focus on exploring the students' understanding of moral values in the local narratives constructed during genre writing activities. This paper also describes the teacher's feedback on the students' writing quality. This study involved 20 students from the English Education Department of Muria Kudus University. Guided questions were used in the interview session to explore the students' understanding of the local narratives and moral values. The review of students' papers was used to analyze the teacher's feedback to explore the students' quality of writing.

Keywords: local wisdom; narrative; character building; writing.
\end{abstract}

\section{INTRODUCTION}

The function of Indonesian national education is to develop human capabilities and to form the national character and national civilization in every citizen's thought and behavior. It intends to educate and to improve the nation's life and aiming at developing potential students so that they become great believers and worshipers of their God (Kurniawan, 2014).

The development of the students' characters is very important so that the generations will not be defeated by global competition. Character building must be adapted for the noble values of our culture. The character of a nation is a combination of all the characteristics of a nation. It includes the physical, intellectual, and moral characteristics of all the citizens and individuals. Building the characters of the nation does not mean building intellectual capability or physic, or by only explaining about moral issues in the classroom. We need the whole aspects to be integrated into the learning process. This character building is a combination of intellectual power and human life skill. Indonesia consists of many local ethics and tradition; therefore, it is very important to hold on to the development of the local cultural values from the community. The values can be introduced to students through the teaching and learning process at schools to preserve the tradition and to instill the national identity of our nation.

According to Damayanti (2013), local wisdom can be interpreted as good cultural values that exist within a society. This means that every society has a noble order or values that have been taught generation after generation. To know local wisdom in a region, we must be able to understand the noble cultural values that exist within the region.

Kudus is a small city in Central Java with diversity found in its community. Starting from religion, work, to culture. In Kudus, there are also two figures from Walisongo who spread Islam in Java in ancient times. The two guardians were Sunan Muria or Raden Umar Said and Sunan Kudus or Sheikh Ja'far Shodiq. It is not surprising if the city of Kudus is also known as the City of Santri, because there are many Islamic boarding schools spread in the Holy City, Kudus (Kompasiana, 2016; Indrahti, 2012)

The philosophy of Sunan Kudus is described by the acronym Gosjigang which means Gus or 'good', ji means 'recite', and Gang means 'trade'. Through that philosophy, Sunan Kudus guided his followers and the Holy community to become people with good personalities, diligent in reciting, and willing to try or trade. Thus, this philosophy becomes the guidance of life for the 
Kudus community (Widi \& Burhanuudin, 2011; Maharromiyati \& Suyatmo, 2016).

In learning English, folklore is usually taught in the sub-theme 'narrative'. Narrative text is a type of text that tells a story or event that has been inherited from time to time. Texts which include narrative are legends, folklore, myths, etc. What is interesting about the narrative is that each story usually holds a moral message that is full of noble characters.

For students, narrative writing is not simple. Many of them think that writing is the language skill in which even a native speaker still has problems to acquire it. It means that writing is not simply language written on paper. It is more complicated and it needs more practice to improve it. Therefore, a writer needs some knowledge about writing and writing technique and must practice it regularly (Norrish in Sulistyo, 2013). To be able to write, a writer needs to acknowledge the crucial aspect of language and genre.

Derewianka in Tuan (2011) says that genre can be defined as specific text-type which results from using language (written or spoken) with predictable and recurring patterns to accomplish something in everyday, academic and literary text within a particular culture. Therefore, genres are associated with the particular purpose, stages and language features. The communicative purpose represents the purpose of using the language, for example, if people want to explain the step of doing something, they use procedures. On the other hand, if they want to entertain the reader/hearer by using stories, they use narratives. This definition is also supported by Paltridge (2001) and Knapp and Watkins (1994) in Melissourgou and Frantzi (2017). They connect the term genre to language processes, such as describing, explaining, and arguing and consider the term text type as products of language usage or things, such as reports, expositions, and stories or narrative.

Masoni states that narrative text usually presented an imaginary story derived from the author's imagination or can be based on a real event adopted by the author or can be a combination. Folk refers to stories without a precise author, and it is told by many people in the society, which range from fictional genres, such as fairy tales to jokes, legends or personal experience tales (Masoni, 2018)

Recently, in Indonesia, the teaching and learning writing is shifted to text-based writing. The focus of writing is no longer on grammatical orientation, but it enhances the more complex way of writing qualification, such as genre focus, and it includes the cohesion and coherence aspects. Narrative as one of text types has been introduced from school level and university level, but writing difficulties seem to be the problems of many teachers. Sulistyo (2013) finds out that writing problem which might be faced by students usually due to understanding the generic structure of written narratives. They miss the concept of applying the generic structure of written narratives. It might be because they are incapable of differentiating the orientation, evaluation, complication, resolution, and re-orientation, therefore, they make some errors in identifying the sentence patterns used in every generic structure. In line with the problem above, Wibowo (2013) states some writing problems which occur in writing process, such as students have difficulties expressing their idea into written form. Especially in writing narrative text, students have to express their ideas to make a story that entertains the reader.

Lirola (2015), in her research, focuses on the use of genre-based theory to teach writing. She reveals that using the theory of genre as a framework to teach academic writing helped students to improve their writing skills. The results show that providing students to good models of different text types, and directing them to write texts based on these models, improves students' writing from the grammatical level to the whole textual point of view. Luthfiyati, Latief, \& Suharmanto (2015) research students' mistakes in writing narrative at the level of senior high school in Lamongan. They claim that students made mistakes in expressing moral value, in expressing content, and in using organization, grammar and vocabulary. Khunzunuddin (2017) examines the oral stories in the form of folk (myths, legends, and myths) of the Kudus society. He found the folk story of "Dewi Nawangsih and Bagus Rinangku", the legend of "Karangbener", and the myth of "Kyai Telingsing" have the same narrative structure in the function of the knights' story of leaving home. Likewise, the prose story of the people "Dewi Nawangsih and Bagus Rinangku", the legend of "Karangbener", and the myth of "Kyai Telingsing" have similar values in aspects; a) environment, b) responsibility, c) religion, and d) social (Khunzunuddin, 2017).

This current research focuses on analyzing the students' understanding of local values in Kudus implied in the stories. The writers also present the teachers' writing feedback. This 
research is conducted at a university-level education in a genre writing class. The students are asked to write narrative texts based on the local folklores in their home town. The students are also asked to analyze the moral values which are implicitly carried out in each story and mention them as the coda. To illustrate the quality of the students' narrative writing, the writers also analyze the teachers' feedback.

Briefly, this paper has two purposes. First, the writers focus on exploring the students' understanding of moral values which are stated in the students' narratives texts as coda and describing the teacher/lecturer's feedback on the students' writing quality as the works are being reviewed by the teacher.

\section{METHOD}

The research conducted at the English Education Department, Muria Kudus University in Kudus Regency involves 20 students. To explore the students' understanding of the moral values, the students are assigned to compose narratives text based on the local folklores in Kudus. Classroom discussions were conducted to let students share their stories and tell the moral values they find out after understanding the stories. During this process, the students are given some questions related to the moral values and the kinds of folklores they already know. At the end of this session, students are assigned to write narrative texts. When the writer observes the students while they are writing the narratives, it was found that the students encounter many problems. Therefore, this research also explores the teachers' feedback to overview the quality of the students' writing.

Here, FGDs were used to organize the students in exploring their understanding of their local narratives and values. This discussion facilitates the students to share their understanding and to enrich their knowledge on Kudus local narratives. Interviews were equipped with guided questions to explore the students' understanding of the local narratives and moral values. Documentation was also used during the review of students' papers. This aims to analyze the teacher's feedback to illustrate the students' quality of writing.

\section{RESULTS AND DISCUSSION}

\section{The students understanding on local values}

The influence of Hindu Culture is caused by the existence of Hindu kingdoms which was spread out across Java Island in ancient times. Islam is introduced by Sunan Kudus through several approaches. He spreads Islamic teachings very smoothly by preserving the previous tradition established by Hindu beliefs (Pradisa, 2017). These following values are some moral values identified by the students after understanding some local narratives. Value refers to something or concept of high value that is believed or respected and used as individuals' way of life. Therefore, values are used as social rules of a person or group of people in their daily life as ways of thinking, speaking and acting. The EED students regard the values as the rules to socialize with others, in the narrative story of the people in Kudus, they found various values, such as cultural, social, religious, environmental, and responsibility values. Table 1 presents the list of moral values summarized from the stories written by the students.

Table 1. List of moral values mentioned by the students

\begin{tabular}{|c|c|}
\hline $\begin{array}{l}\text { Moral } \\
\text { Value }\end{array}$ & Interpretation \\
\hline Honesty & $\begin{array}{l}\text { Honesty is a moral value that attributes } \\
\text { to integrity, truthfulness, } \\
\text { straightforwardness, including } \\
\text { straightforwardness of conduct. }\end{array}$ \\
\hline
\end{tabular}
trustworthy, loyal, fair, and sincere. This value is well reflected in the story of Majapahit Gates as Kebo Anabrang tries to complete the task from Sunan Muria to bring the Majapahit gate to Kudus.

Value on Creating values of others means others respecting and appreciating the existence of other people by maintaining a good manner. This value often contributes to other values, such as respecting others. This value is found in the story of Ki Ageng Kedu who does not value the existence and power of Sunan Kudus, he finally receives his punishment.

Maintain Religious values are principles found in religious any religious traditions, thoughts, and value beliefs. Religious-based values are based on scriptures and a religion's established norms. Kudus was ruled by Hindu Kingdoms long before Islam was introduced. The religious value is carried out at most of the folklores. This story is told in the religious folk Syeh Ja'far and Kyai The Ling Sing as the former of Islamic religious teaching.

Entrepre Entrepreneurship value relates to the neurship spirits of the people who believe in value trade to maintain their economic life. 


\begin{tabular}{ll}
\hline & This value lies behind the history of \\
& Asal-Usul Kota Kretek, in which the \\
trade of Tobacco leaves was introduced \\
by Ki Agen Kedu.
\end{tabular}

Many local folks written by the students are related to figures who have been the establisher of Islamic culture. One of the famous ones is the folk of Bulusan. This story related to Sunan Muria. Bulusan (also called Bulusan Tradition) is one of the traditional celebrations in the Islamic community in Kudus, Central Java, Indonesia, which held seven days after Eid. This tradition comes from folklore related to Sunan Muria. He cursed the villagers who still work in the fields at night during Ramadan on the eve of Revelation of the Qur'an so that residents turn out to be turtles (bulus). Sunan Muria stuck his stick into the ground, out 48 springs or sources. The springs are then becoming the name of the village, namely Dukuh Sumber. Once these places inhabited, Kyai Dudo then asks every 7 th Shawwal to create a ritual to pray for two of his students who were condemned for being turtles. Ritual prayer followed by the rest of society is then referred to as a tradition Bulusan. It became an interesting spectacle for Kudus society today. Bulusan tradition today not only presents a ritual prayer in Petilasan Kyai Dudo, but also a variety of other activities, including a parade of music and other stage entertainment (Suciati \& Erzad, 2018).

One of the folks also told about a tragic love story between Dewi Nawangsih and Raden Bagus Rinangku. Raden Ayu Dewi Nawangsih is the daughter of Sunan Muria who was proposed by Raden Bagus Rinangku. However, Sunan Muria disagrees because of Bagus Rinangkul's personality that is considered challenging. Spontaneously, Sunan Muria launched an arrow accurately to Bagus Rinangku and it passed through his back chest. Seeing her lover died, Dewi Nawangsih bumped into him, so the arrow also injured Dewi Nawangsih which then resulted in her death. The bodies of the two lovers cannot be separated, they were then buried together. The students find that this story included some moral values that parents and children should build a good relationship by developing a good communication.

Another story is about the legend of Jember Village. This story was written by the students in their writing task. This story is about the son of Sunan Kudus who was assigned by his father to spread the teaching of Islam in Kedu, Salatiga. Sunan Kudus's son approached them by following the cockfight game. The chicken of Sunan Kudus's son won the game. Ki Ageng Kedu then challenged the son of Sunan Kudus by betting the clothing they wear, finally, Sunan Kudus's son lost the game. Then the son of Sunan Kudus came back home and report to his father. To re-challenge Ki Ageng Kedu, to take back his clothes, finally, the son of Sunan Kudus managed to win the game. Realizing his loss, Ki Ageng $K e d u$ realized that who defeated him surely was the son of a Wali (orang jaduk) great person.

Because of the defeats, Ki Ageng kedu got more curious and wanted to try the miracle of Sunan Kudus, then he visited the city of Kudus by riding a bamboo plait to show off his power to Sunan Kudus. Suddenly, Sunan Kudus, in front of him said: "Hai Ki Ageng Kedu, I'm in here". The Tampah he drove suddenly shuffled here and there, uncontrolled, his light body suddenly turned heavy and was immediately sucked by the gravity of the earth, it was like being knocked down by invisible forces. Ki Ageng Kedu body 
was thrown into the muddy ground of the sewer area. In Javanese language called "Ngecember" until now, the place name is called Jember Village.

Students learn many moral values from this story. When they analyze Ki Ageng Kedu's attitude, it reflects high arrogance. He thinks that he is a great man who cannot be defeated by others. Sunan Kudus with the gifted power, drawn the arrogance. From the story, students learn that they should not be arrogant for what they possess because someone out there might be more capable than us. Not being arrogant also means appreciating other people. Javanese wisdom teaches us to appreciate others. Therefore, in Javanese culture, we know three levels of language and the different registers in using the language. The appreciation of others is reflected in the use of the different levels of the language. The human appreciations include appreciating elder people, teachers, saints, parents, and people from a higher level of society.

Another story of the local narrative in Kudus is the story of Majapahit Gate. This is the story of a young man named Kebo Anabrang or commonly called as Kebo Nabrang. One day, Kebo Anabrang met Kanjeng Sunan in his school (padepokan). Kebo nabrang went to padepokan Kanjeng Sunan to confess that he was the son of Kanjeng Sunan Muria. Since his childhood, Kebo Nabrang had never seen his father. His mother told him that his father was Sunan Muria. However, he was strongly rejected by Sunan Muria. He said that he never had a child named Kebo Nabrang. Because Kebo Nabrang constantly urged, Sunan Muria finally said that he was willing to admit that Kebo Nabrang was his son, with a condition; Kebo Nabrang must be able to move one of the gates of Majapahit kingdom to Mount Muria in one night.

Kebo Nabrang could indeed carry one of the gates himself to be taken from Majapahit to the mountain of Muria. Yet, unlucky for Kebonabrang, at the same time in Juana, east of Pati, there was also a young man who was heading to Majapahit to follow the contest to move the gate of Majapahit. The contest was to win a beautiful princess named Roro Pujiwati, the daughter of Kyai Ageng Ngerang (Sunan Ngerang) Juana.

Kebo Nabrang who had successfully brought the gate was stopped by Raden Ronggo and there was a fight between them. The fight between the two young men was known by Sunan Muria. He went to the place where the two young men fought. The place is now called Towelo village (from Cetho welo-welo).

It seemed that Raden Ronggo is not strong enough to lift it. By Sunan Muria, Raden Ronggo was only given a bar, which was then taken to Juana, handed over to Kyai Ageng Ngerang. Yet, Kyai Ageng Ngerang refused to accept the contest because the requirement was not a doorstop, but the gate. Because of anger, the wooden bar was swung to Roro Pujiwati, but a miracle happened, the wooden bar was not falling on Roro Pujiwati, because there was a voice from the dark and at that time the night was dark, on the night of 15 Sha'ban (Ruwah) and vanish Roro Pujiwati without a trace, somewhere.

Meanwhile, Kebo Nabrang was welcomed to bring the gate of Majapahit to Mount Muria. Yet, when it was just lifted, there was the sound of crowing chickens, a sign of morning. Then Kebo Nabrang finally failed to meet the requirements demanded by Sunan Muria. Kebo Nabrang was then ordered to guard the gate of Majapahit until his death.

The moral value of this story is a child should have a responsibility to gain a huge trust and he should be confident and remain humble in an attempt to prove the love for parents through a difficult task. If we want to get something, we should try to get it in any way even though by risking our life.

Kudus is considered the center of Islamic culture in its district and widely known as Islamic religious society. It is because the spread of Islam is influenced by two saints, namely Sunan Kudus and Sunan Muria. Now, the influence of the figures can still be seen in several buildings that keep the histories and the folks of the Islamic development in Kudus. Besides, the old buildings are now considered as the local heritage. Some traditions are preserved for generations, such as Buka Luwur, Dukderan, Bulusan and others which are celebrated due to the historical and religious values.

\section{The teacher"' feedback}

Teacher's feedback has an essential role in students' writing process. It helps students to identify their strengths and weaknesses in developing their writing project, this will make students know what to do to make improvements on their writing and at the same time learning to organize their ideas based on the local folklore.

Teacher's feedback, if it is addressed effectively, can also contribute to students' second language acquisition. In this research, 
there are several aspects of teachers' feedback that will be highlighted. Some specific comments from the teachers are:

1. The generic structure of the narrative text is not well applied.

2. The teacher does not understand some of the underlined phrases. "Can you rewrite this sentence?" Students need to rewrite the phrase.

3. Students need to provide specific details to tell the story clearly and engagingly. There are more confusing plot and text structures.

4. The writing has already presented a well simple structure, but it needs improvement in the choices of words and phrases.

5. The text implies the local folklore in Kudus, but it needs improvement on variety of linguistics features.

6. This gives excellent example moves on narrative and you need to add your argument on local values.

7. Students need to build up a transition clarifying the connection between the sentences.

8. There is a lack of connection between ideas in the paragraphs.

9. The organization of the ideas and the sentence structures are much influenced by the form of $L 1$. There are inappropriate English expressions that may be caused by direct translation.

In general, all students have good control of the obligatory constituent structure of narratives proposed by Joyce and Feez (2000) that includes orientation (introducing the story), complication (problem arise), and resolution (the resolution of the problem). Moreover, one of the narrative structures which is sequence of events as proposed by Anderson and Anderson (2003) is also found in the students' writing. Students well address the sequence of events, though missing links between the events are still emerging in some of the works. How the characters react to the complication in chronological order sometimes is not clearly stated.

Coda as the optional structure of narratives that should be found in the last text sometimes is not mentioned by the students. Coda consists of comments about the future lives of the character such as; they lived happily ever after. Coda also contains some information about moral values implied in the story. It is presented at the end of the stories to emphasize that the story is told to give moral values.

In terms of linguistic features, the students still need more practice in writing a narrative text especially in the specific language features, such as tenses and word choices. In some texts, there are some inappropriate linguistic features of narrative exist, for example the use of specific participants and the use of linking verb to indicate the time sequences. Moreover, in a few of the students' text, past tenses as one characteristic of narratives do not appear. Some students still face a lot of difficulties in writing narratives. There are more errors in the linguistic features of narratives. More than once, the students make a lot of grammatical errors.

However, some achievements are found in the students' writing. The language features of narratives can be found, namely; 1) the use of past tense, 2) the use of action verbs, 3) the use of temporal conjunction, 4) the verbal and quotation existence, 5) the use of personal pronouns, and 6) the description of time and place.

Past tenses are used to indicate that the story is happened in the past. Minor and major grammatical errors are found in some of the students' works. Therefore, students still need to make some revisions due to different use of past tenses and present tenses. Although in narrative writing, it is dominated by the use of past tenses, minor present tenses are sometimes used to indicate a verbal quotation. Furthermore, in terms of narrative's language features, different students from different levels of achievement have different abilities in applying the features in the story. In conclusion, some students still have lacks knowledge of linguistics features of narratives.

The findings of this study indicate that some students from all levels of achievement have been aware of generic structure of narrative text that includes orientation, complication, and resolution; although in some of the writing we still cannot find clear distinction of each step of the structures. For example, at the beginning of a narrative, the writer usually introduces the story by indicating the time, place and main character. Some writers start their narrative with limited orientation and sometimes it was seen like they directly jump to the complication.

Based on the findings, teachers need to find some approaches and techniques in teaching writing to improve students' abilities, particularly in narratives. They need to gain more information about each students' characteristics especially low achievers since they need more guidance in writing narratives. Students and teachers also need to explore more on the local narrative to understand their identity as members of society. Local folktale should be told over generations to preserve local wisdom and to introduce them in writing classes could help the students to become agents in preserving tradition as their local 
heritage.

In writing classes, the importance of feedback is considered as part of the teacher's pedagogical practices. Students should be able to comprehend the teachers' feedback they find in their writing. Developing well-structured writing should be the responsibility of the learners and teachers. The importance of the teachers' written feedback has largely been documented by previous research in the areas of ESL and EFL writing. In both English language teaching contexts, especially in classrooms where the teaching of writing is process-oriented, teachers and students have acknowledged the crucial value of the teacher's written feedback which is not only facilitating students' revisions, but also assisting them during the step to step learning-to-write process (Harmer, 2004; Peterson, 2010).

In this research, there are some points can be concluded as the basis of teachers' writing feedback.

1. Grammar point/linguistics features

The students' writing has already presented well structure, but it needs improvement in the choices of words and phrases. The texts imply the local folklore in Kudus, but it needs improvement on variety of linguistics features. The narrative linguistics features use past tense to indicate the past event and also present some present tense to indicate quotation or verbal language. Some students still use many simple present tenses to indicate past events.

\section{Punctuation point}

Students need to build up a transition clarifying the connection between sentences. In this case, students need to think of the appropriate way to connect the sentences or clauses by using correct conjunctions or punctuation. There is a lack of connection between ideas in the paragraphs.

3. Vocabulary point

The organization of the ideas and the sentence structures are much influenced by the form of L1. There are inappropriate English expressions that may be caused by direct translation.

4. Generic structure

Some writings have given excellent example moves on narrative, although students need to add argument on local values as coda. The generic structure of the narrative text is not well applied. The teacher does not understand some of the underlined phrases; therefore, students need to rewrite the phrase. Students need to provide specific details to tell the story. There are more confusing plots and generic structures found in the students' writing.

\section{CONCLUSION}

Kudus is also well known as 'Kota Santri' or the city of Islamic students. In this regency, there were two Sunan; Sunan Kudus and Sunan Muria. Both of them are also called Walisanga. Many local narratives are told and they bring local values related to the former of Kudus. Many folks are related to figures who have been the establisher of Islamic culture.

The texts imply the local folklore in Kudus, but they need improvement on variety of linguistics features. The narrative linguistics features use past tense to indicate the past event and also present some present tense to indicate quotation or verbal language. Some students still use many simple present tenses to indicate past events. Students need to build up a transition that helps to clarify the connection between sentences. In this case, students need to think of the appropriate way to connect the sentences or clauses by using correct conjunctions or punctuation.

Naturally, students concern more about their grading result then improving their skill and they have less interest in revising their work as feedback is provided on their work. Students need more encouragement to actively involve in the learning-to-write process and do what their teachers suggest them to improve their writing. Teachers should clearly explain the assessment criteria as well as the meaning of different codes they use in their error-feedback. The students should be allowed to participate in the decision of the assessment criteria to provide them with information about what should they do to develop good written narrative texts.

Learning narrative is not only learning the language features or the generic structure. It is also part of learning moral values. Teachers should use narratives as the media of teaching writing and also instilling moral value. Moral values are also part of national identities. To make the students aware of the moral values, teachers can design the class by making group discussion, the writing class may not only concern on writing instruction but also discussion on the local values.

To get the students' improvement in writing, teachers also need to give some positive feedback for further revision. Responding to student writing is a crucial component of the teaching-towrite process. Furthermore, students' access to the teacher's feedback and their effective use of it contribute to important aspects in the way their learning-to-write process. 


\section{ACKNOWLEDGMENT}

We would like to show our greatest gratitude to the Research Department of Muria Kudus University and other parties who contribute to this research.

\section{REFERENCES}

Alyousef, S, H., \& Alyahya, M, A. (2018). The conceptualization of genre in systemic functional linguistics. Jurnal RETORIKA: Jurnal Ilmu Bahasa, 4(2), 91-99. doi: 10.22225/jr.4.2.665.9199.

Anderson, M., \& Anderson. (2003). Text types in English 1-2. Australia: Macmillan.

Damayanti, I. (2013) Kearifan lokal Kabupaten Kudus. Retrieved on May 24, 2018 from http://damayantiirma03.blogspot.co.id/2013/12/k earifan-lokal-kabupaten-kudus.html.

Harmer, J. (2004). How to teach writing. Edinburgh Gate: Pearson Education Limited.

Hyland, K. (2004). Genre and second language writing. Michigan: University of Michigan Press

Indrahti, S. (2012). Kudus dan Islam: Nilai-nilai budaya lokal dan industri wisata ziarah. Semarang: CV Madina. Retrieved from http://eprints.undip.ac.id/39024/2/buku_KUDUS _DAN_ISLAM.pdf.

Joyce, H. D. S., \& Feez, S. (2000). Creative writing skill. Albert Park Vic: Phoenix Education.

Knapp, P., \& Watkins, M. (1994). Context-textgrammar: Teaching the genres and grammar of school writing in infants and primary classrooms. Sydney: Text productions.

Kompasiana. (2016). Gusjigang sebuah ajaran Sunan Kudus yang mendalam. Retrieved from http://www.kompasiana.com/radenbaguska/gusji gang-sebuah-ajaran-sunan-kudus-yangmendalam_56909b8bdb93735f11b618ea.

Kurniawan. (2014). Menanamkan pendidikan karakter dengan strategi pembelajaran afektif. Retrieved May 24, 2016 from http://www.membumikanpendidikan.com/2014/0 5/menanamkan-pendidikan-karakterdengan.html.

Lirola, M. M. (2015). The use of genre theory for improving writing proficiency skills in explanations. Ikala, 20(2), 189-204.

Luthfiyati, D., Latief, M. A., \& Suharmanto. (2015). Mistakes in writing narrative texts made by the students of senior high school. Jurnal Pendidikan Humaniora, 3(2), 161-164.
Maharromiyati, M., \& Suyahmo, S. (2017). Pewarisan nilai falsafah budaya lokal Gusjigang sebagai modal sosial di pondok pesantren entrepreneur Al Mawaddah Kudus. Journal of Educational Social Studies, 5(2), 163-172. Retrieved on December 1, 2018 from https://journal.unnes.ac.id/sju/index.php/jess/artic le/view/14082.

Masoni, L. (2018). Folk narrative and EFL: A narrative approach to language learning. Journal of Literature and Art Studies, 8(4). Retrieved May $\quad 13, \quad 2019$ from https://www.researchgate.net/publication/324449 576_Folk_Narrative_and_EFL_A_Narrative_Ap proach_to_Language_Learning.

Melissourgou, M. N., \& Frantzi, K. T. (2017). Genre identification based on SFL principles: The representation of text types and genres in English language teaching material. Corpus Pragmatics. doi: 10.1007/s41701-017-0013-z.

Paltridge, B. (2001). Genre and the language learning classroom. Ann Arbor, MI: University of Michigan Press.

Peterson, S. S. (2010). How can feedback be used as a teaching tool to support students' writing development? Retrieved from http://www.edu.gov.on.ca/eng/literacynumeracy/ inspire/research/whatworks.html.

Pradisa, A. P. S. (2017). Perpaduan budaya Islam dan Hindu dalam Masjid Menara Kudus. Prosiding Seminar Heritage IPLBI.

Suciati, \& Erzad, A. M. (2018). The existence of Kudus Islamic local culture to prevent radicalism in globalization era. Qijis, 6(1).

Sulistyo, I. (2013). An analysis of generic structure of narrative text written by the tenth year students of SMA Yasiha $\mathrm{Gu}$. Retrieved from: https://www.researchgate.net/publication/322205 527.

Tuan, L. T. (2011). Teaching writing through genrebased approach. Theory and Practice in Language Studies, 1(11), 1471-1478.

Wibowo, K. A. (2013). Improving student's writing ability in narrative text by using chronological 3D pictures as media. Journal of English Language Teaching, 2(1).

Widi, H., \& Burhanudin, M. (2011). Gusjigang: Sunan Kudus melintas zaman. Retrieved from http://nasional.kompas.com/read/2011/08/02/122 21026/. 